\title{
A Study of the Effect of Using Narratives on Iranian EFL Learners' Reading Comprehension Ability
}

\author{
Moussa Ahmadian (Corresponding author) \\ Associate Professor, Dept. of English Language and Literature, Faculty of Humanities, Arak University \\ Arak 38156-8-8349, PO. Box: 879, Iran \\ Tel: 98-861-313-5111 E-mail: M-ahmadian@araku.ac.ir \\ Tel: 98-9181611261_E-mail: Moussa_ahmadian@yahoo.co.uk \\ Ashkan Pashangzadeh \\ MA in TEFL, Dept. of English Language and Literature, Faculty of Humanities, Arak University \\ Arak 38156-8-8349, Iran \\ E-mail: Ashkan.Pashang@yahoo.com
}

Received: 01-02-2013

Accepted: 26-03-2013

Published: 01-05-2013

doi:10.7575/aiac.ijalel.v.2n.3p.153

URL: http://dx.doi.org/10.7575/aiac.ijalel.v.2n.3p.153

\begin{abstract}
The importance of narratives as a significant type of literary texts and their presence in all aspects of society and social experiences of ours by and large is not hidden to anyone; the ever-presence of narratives in every age, every place and in every language is completely tangible. As such, the role and influence of narratives in language learning and in teaching an L2 have almost ever been a considerable debate among experts: psycholinguists, SLA researchers, and language educationalists. In this respect, the present study attempts to investigate the relationship between the use of narratives in EFL environments and its probable effects on EFL learners' reading comprehension abilities compared to using non-narratives. To do so, 87 Persian native-speaking Arak university students majoring in English Translation were selected from among 98 ones and were put into three homogeneous intact groups: two experimental groups, namely, Narrative and Non-narrative groups (consisting of 28 and 35 participants, respectively) and one control group consisting of 24 participants. Three short narrative texts and three non-narrative ones with Flesch Reading Ease scores between 65 and 75 were selected from a large body of existing texts and were used as tasks of elicitation. The results of statistical comparisons between the performance of the groups indicated the over performance of the Narrative experimental group over the Non-narrative experimental group, and both experimental groups over the control group, thus showing the effects of using narratives on EFL learners' reading comprehension ability. Possible reasons for this over-performance and implications of the findings for language teaching will be discussed.
\end{abstract}

Keywords: Narrative, Non-narrative, Reading comprehension, Second language acquisition, Language Teaching

\section{Introduction}

Franz Kafka (1940) once said that the book is the axe by which we break open the frozen seas within us. This metaphorical expression signifies that reading books has the power to open up persons' emotions and sometimes have the power to change the majority of our opinions. Meanwhile, reading stories and generally literary works enables us to put our own feet into other people's shoes to have experience on their psychological, social, economic and imaginative life. If so, then by reading we can find out the reality of other points of view that comes from other people irrespective of their cultural or linguistic background. In addition, learning to read is particularly important for several purposes ranging from general learning to academic achievements. There are findings in applied linguistics and reading research (Musen, 2010; Kong, Powers, Starr, \& Williams, 2012) that confirm a close relationship between reading ability and educational success from primary schools to institutions of higher education: those students who are more experienced in reading and who comprehend what they read typically get higher marks (Pretorius, 2002). According to Chastain (1988, p. 216), "reading is a basic and complementary skill in language learning." Also, reading comprehension in second or foreign language contexts, particularly reading authentic materials, can help second language (L2) learners develop their communicative ability.

One of the most important sources in foreign or second language teaching has been always literary texts, since they represent a variety of language use in different (authentic) contexts. Ronnqvist and Sell (1994) stipulate that the reading of literary texts in the target language (TL) provides L2 readers with authentic and simply obtainable experience in the pragmatic aspects of the TL regarding the fact that literary texts have the ability to relate formal linguistic expression to situational and socio-cultural contexts. During the past two decades, focusing on literature and its role in language development in general and in L2 teaching and learning in particular have caught language educationalists' attention. Carter (2007) asserts: 
In many contexts of teaching and learning language and literature, the predominant view that has emerged over the past twenty years is that 'literary' texts are socially, culturally and historically variable, should be defined as part of institutionalized social processes, and are discourses that, far from being separate from other discourses, share characteristics with them (p.5).

In the same line, the role of narratives as a type of literary texts in language teaching environments seems to be unquestionable. Narratives, in one form or another, seep into almost all aspects of society and social experiences of ours. Narrative forms are found not only in the literary contexts but also in the remembrance of life events, in textbooks and historical documents, in scientific data explanations, in political speeches, and in day-to-day conversation (Nash, 1994). Even some people believe that all human knowledge is naturally narrative-based (Schank \& Abelson, 1995).

Narratives, whether verbal or visual, mediated or face-to-face, constitute one of the most prevalent types of discourse. It seems that narratives demonstrate essential potentials as instruments in second language learning environments. Narrative texts can motivate L2 learners of different levels of language proficiency, different age groups to be eagerly involved in a wide range of classroom activities and to improve and develop their skills in the TL (Birlik \& Salli-Copur, 2007). Narratives have also been usually used as linguistic resources for language teachers in second or foreign language teaching area (Ahmadian, 2011). Despite all these facts, and the fact that many people have claimed that the use of literary texts, because of their nature, is of high significance in L2 learning and even in FLA (Bakhtin, 1975; McKay, 1982; Carter, 2007; Paran, 2008; Van, 2009; Hester, 2010; Ahmadian, 2011; Johnson \& Golombek, 2011; Khatib, Rezaei, \& Derakhshan, 2011; Knight, 2011), less research has been reported to take into consideration the effects of using narratives on language learning in general and development of L2 reading comprehension ability in particular. This paper, thus, aims to examine the effect of using narrative texts in EFL classrooms on learners' improvement of reading comprehension ability.

\section{Literature Review}

The use of narrative literature in language teaching and learning has sometimes been a matter of debate among the opponents and proponents. For instance, Edmondson (1997), in general, believes that literature has nothing to do with foreign language education. She (1997) stipulates that "literary texts have no special status as regards their relevance to and utility for the business of achieving proficiency or general competence in an L2." He further adds that “... as regards their potential use in teaching programs, literary texts have no 'essence' that distinguishes them from other types of text" (p.45).

According to McKay (1982), literature is immersed culturally in specific concepts which, consequently, make it sometimes frustrating to understand. He (1982) also argues that in specialized disciplines ranging from zoology to biology or in academic environments where didactic objectives take priority over aesthetic aspects of literary texts, literature has little if any to meet the needs of learners. Nineteen years later, she (2001) asserts that the use of literature as the content of $\mathrm{L} 2$ teaching and learning environments offers three productive advantages:

a) Literary texts, depending on how the language is used to create a particular effect, demonstrate for learners the importance of form in achieving specific communicative goals.

b) Using literature as content in the L2 classrooms provides an ideal basis for integrating the four skills.

c) In an area when English is used in a great variety of cross-cultural encounters, literary texts are valuable in raising students' and teachers' cross-cultural awareness (p.319).

Kramsch (1993, p.130) remarks that, "the main argument for using literary texts in the language classroom is literature's ability to represent the particular voice of a writer among the many voices of his or her community and thus to appeal to the reader in particular". Savvidou (2004) argues that acquiring communicative competence is EFL teachers' main concern to help learners however they may have a tendency to give attention to teaching standard forms of language expressions. Developing communicative competence is something beyond achieving even a high level of mastery in using structures and forms, it, rather, includes improving the ability of discourse interpretation based not only on linguistic knowledge but also on knowing a variety of social and cultural contexts. Using literature in the EFL contexts can thus offer learners influential and effective teaching materials to go beyond linguistic structures and develop their communicative ability to be creative in language use. Tuker (1991, cited in Aghagolzadeh and Tajabadi, 2012) argues that literature is capable of expanding all language skills through its extensive and connotative expressions and constructions, and its complex syntax. Oster (1989) states "literature helps students to write more creatively" (p.85).

In this respect, the position of narratives as an important type of literary texts and their presence in all aspects of society and social experiences of ours is not hidden to anyone. As Barthes argues (1977 P: 79), "narrative is present in myth, legend, fable, tale, novella, epic, history, tragedy, drama, comedy, mime, painting, cinema, comics, news item and conversation". Accordingly, a vast variety of narratives can be seen in all aspects of life and society; it appears that narratives do exist with the history of human race and there is no place with people lacking narratives.

Schank and Abelson (1995) believe that all human knowledge is narrative-based. They claim that "virtually all human knowledge is based on stories constructed around the past experiences" and "new experiences are interpreted in terms of old stories" (p.1). Intuitively, they believe that almost any knowledge irrespective of whether being fact or belief, originates from storytelling and story understanding.

Narrative texts have always been considered as working and insightful sources of materials for language teaching and learning, since they show high potentials in a vast and broad variety of language use in authentic contexts. Narratives are used in both L2 contexts and in L1 contexts. According to Ahmadian (2011), parents and care-takers use narratives 
for enhancing the exposure of children to language in order to facilitate children's linguistic competence achievement, and language teachers have used, and still use, narratives in kindergartens and primary schools to enrich native speaking children's language skills such as reading comprehension, writing abilities, retelling abilities and discussion skills. Ahmadian (2011) also explains that using narratives as teaching materials may lead to enhance development of cultural and communicative competence for social and interpersonal interactions. As such, he stipulates, "language teachers use narratives for the same or similar purposes in L2 contexts" (p.2).

In the grammar translation method, in second language teaching area, narratives were used to provide second/foreign language learners with genuine samples of the TL. Narrative literature not only has been applied as an important device in order to teach words, grammar and structure of the TL, but also it played a crucial role in introducing cultural aspects of the TL societies and, consequently, opened new horizons in front of the eyes of second or foreign language learners. As Ahmadian (2011) points out, short narratives were designed and modified to be used in direct and audio-lingual methods in order to expose learners to appropriate samples of the target language use. Narratives were used in the form of short dialogue, and role-playing to provide favorable circumstances for more different drills and pattern-practice exercises of key structures.

Smith (2007) mentions that researchers and theorists have highlighted the significance and influence of narrative structures in various aspects of human life including personal and social alterations, identity development and critique, social interactions, self-perceptions, and collective knowledge, etc. Smith (2007), then, concludes: If social work educational settings were seeking a rational justification for using stories (be in biographical or fictional forms), the narrative inquiry in education now suggests such a landscape.

Holloway (2009) conducted a study to examine "the use of fiction to explore difficult issues such as race, gender, culture, power, and privilege, and ways to promote these kinds of discussions amongst teacher candidates" (p.1). She concluded that "fictional literature provides a vehicle for students to discuss power issues and thus achieve a better understanding of identity politics and systemic barriers that shape people's lives" (p.1).

Rutten, Mottart, and Soetaert (2010) in a project aimed to contribute to study on social work education argue that fictional narrative texts, potentially, provide their readers with opportunities for rhetorical analysis through which they can develop their critical awareness and ability. Mar, Otaley, Harish, de la Paz, and Peterson (2006) also found that people who read fiction eagerly received better scores on social ability compared with those who were not interested in reading fiction. Their research also evidenced that "being absorbed in a story also predicted empathy scores" (p. 694). On the other hand, an important question often asked by social work educators is how to encourage social work students to develop an intense and real concern about the lives of the people they will serve in the future, especially when the life experiences of such people are different from the students' life experiences. According to Turner (2012), reading narrative literature, in fiction or biographical forms, encourages social work students to deal with contexts which will help them promote such competence. Turner (2012), furthermore, reports that social work students were asked to choose fictional works whose protagonists' way of life was entirely different from their own. Reading the stories, students reflected their interaction with the characters, explained what they could learn, and described how they would feel if they could meet them, or individuals like them, in the same or similar professional environments. So, by providing such learning environments, students found opportunities to expand their abilities to understand other people's feelings and problems, and to reflect how to develop relationships across different situations. Based on Turner's (2012) findings, some students gained insights into ways of viewing life, as they admitted: “... we should value people for who they are and not what they own or represent because this can be an inaccurate representation of their character" (pp.7-8). Moreover, she concludes, through reading narrative literature, students are offered opportunities to increase and perfect the needed skills and knowledge in real life situations, to achieve a conscious perception of how life may seem to people who live in situations entirely unfamiliar to them, and to develop creative imagination that improves their ability to preserve their self-confidence in protective positions when different options or decision-making are necessary (2012).

Short stories are thus appropriate resources for scrutinizing both language and life, and increasing experiences in both. There are characters in a short story world that live a life like people in the real world. They have active communication and interaction with each other and their environments, and do many things in a variety of satiations, "The world of short fiction both mirrors and illuminates human lives" (Sage 1987:43). Arığul (2001, cited in Hişmanoğlu, 2005), considers using short fictional narratives in the L2 classrooms having the following benefits. They:

a) make the students' reading task easier due to being simple and short when compared with other literary genres,

b)enlarge the advanced level readers' worldviews about different cultures and different groups of people,

c) provide more creative, motivating, and challenging texts that require personal exploration supported by prior knowledge for advanced level readers,

d)motivate learners to read due to being authentic materials,

e) offer a world of wonders and a world of mystery,

f) give students the chance to use their creativity,

g)promote students' critical thinking skills,

h) facilitate teaching a foreign culture (i.e. serve as valuable instruments in attaining cultural knowledge of the selected community),

i) make students feel themselves comfortable and free, 
j) help students coming from various backgrounds communicate with each other because of their universal language

k) help students go beyond the surface meaning and dive into underlying meanings, and

1) act as a perfect vehicle to help students understand the positions of themselves as well as the others by transferring these gained knowledge to their own world (pp. 61-62).

As seen, in spite of almost rich literature on the benefits of using narratives in instructed SLA and classroom activities, the effects of this trend on development of L2 reading comprehension have not been touched upon as it deserves. It was thus that the present study was designed.

\section{The Study}

The present paper investigates possible effects of using narrative texts on Iranian EFL learners' reading comprehension abilities compared to non-narrative ones. In this regard, the study attempts to answer the following questions:

1) Is there any significant relationship between using narratives in EFL classes and improvement of Iranian EFL learners' reading comprehension ability?

2) Is there any significant relationship between using non-narratives in EFL classes and improvement of Iranian EFL learners' reading comprehension ability?

3) Is there any significant priority in using narratives over non-narratives in EFL classes and improvement of Iranian EFL learners' reading comprehension ability?

To provide more objective answers to the above questions, the following null hypotheses were formulated to be tested out:

1) There is no significant relationship between using narratives in EFL classes and improvement of Iranian EFL learners' reading comprehension ability.

2) There is no significant relationship between using Non-narratives in EFL classes and improvement of Iranian EFL learners' reading comprehension ability.

3) There is no significant priority in using narratives over Non-narratives in EFL classes and improvement of Iranian EFL learners' reading comprehension ability.

\subsection{Participants}

A total of 98 undergraduate Persian speaking EFL learners (male and female) majoring English translation at Arak University, Iran, aged 19-23, were asked to participate in the study. Their homogeneity and language proficiency were measured through the Oxford Placement Test (OPT). Taking into account the OPT results, 87 students were selected and put into three homogenous intact groups: two experimental groups, Narrative experimental group and Non-narrative experimental group, and one control group. The Narrative experimental group consisted of 28 participants including 19 females and 9 males, the Non-narrative experimental group was a combination of 22 females and 13 males (35 participants), and the control group consisted of 24 participants 8 males and 16 females.

\subsection{Instrumentation}

\subsubsection{Test of Reading Comprehension}

As mentioned above, the OPT was used to measure the homogeneity of the participants. Moreover, a test of reading comprehension, the Reading Section of TOEFL (1996), as pre- and post-tests, was administered in order to determine the participants' reading comprehension ability before and after the treatment sessions. This section of TOEFL had been already validated by Rahimi, Mirzaei, and Heidari (2012) through 135 junior and senior students majoring ELT and Translation, (55 male and 80 female), at some universities in Iran, aged 18 to 30 (with average age 23). They were representative samples of Iranian L2 learners, since they were gathered from all over the country. The Cronbach's alpha for this test was 0.88 which shows high reliability.

\subsubsection{Tasks of Elicitation}

One of the main requirements of this study was to provide appropriate tasks of elicitation. So, three narrative and three non-narrative texts with certain characteristics were needed. The number of words in each text was decided to fall between 1350 to 1650 ones, neither too long to make the reading process boring, nor too short to ruin the significance and value of texts in the eyes of the participants. Another point which is worth mentioning is that the participants were university students with average of 7 to 8 years of experience in language learning, so the researchers decided to expose them to the texts to be a bit higher than their current competence to make the input as comprehensible as possible (Krashen, 1985) so that they could understand most of them but still remain challenging to make progress. To do so, the texts were selected each with Flesh Reading Ease between 65 to 75 Readability score. Based on Online-Utility.org analysis, on the first reading in the above mentioned Flesh Reading Ease, people are required to have 8 to 9 years of formal education to be able to easily understand the text. Selecting a text with readability score under 50, for instance, makes students to ascertain the meaning by painful and laborious efforts based on persistence and thumbing of the dictionary.

Regarding the criteria mentioned above, and after long and careful evaluations of a large number of narrative texts (including short stories) and non-narrative texts (including various topics, such as History, Social Issues, Sciences, Education, Humanities, Business, etc.) the researchers found five narratives and five non-narratives as more adequate relating to the research purposes. Finally, after further analysis (such as students' interest to the topics), among the five texts, three narratives and three non-narratives were selected and used. Tables 1 and 2, show the specifications of the selected texts. 
Table1. Specifications of the Narrative Texts

\begin{tabular}{lccc}
\hline Narrative texts (title) & Author & $\begin{array}{c}\text { Flesch } \\
\text { Reading } \\
\text { Ease }\end{array}$ & $\begin{array}{c}\text { Number of } \\
\text { words }\end{array}$ \\
\hline It happened on the Brooklyn Subway & Paul Deutschman (2012) & 70.51 & 1,605 \\
\hline The Hungry Man was Fed & Richard Harding Davis & 72.45 & 1,386 \\
\hline $\begin{array}{l}\text { Personal Narrative-Track } \\
\text { Competition }\end{array}$ & unknown & 73.90 & 1,613 \\
\hline
\end{tabular}

Table2. Specifications of the Non-narrative Texts

\begin{tabular}{lccc}
\hline Non Narrative texts (title) & Author & Flesch Reading Ease & $\begin{array}{l}\text { Number of } \\
\text { words }\end{array}$ \\
\hline My Mother Never Worked & $\begin{array}{l}\text { Bonnie Smith-Yackel } \\
(1998)\end{array}$ & 72.85 & 1,373 \\
\hline $\begin{array}{l}\text { Mystery Surrounding the Phoenix } \\
\text { Lights: Evidence of UFO Sighting? }\end{array}$ & unknown & 66.83 & 1,563 \\
\hline The Nature of the Mankind & unknown & 67.23 & 1,622 \\
\hline
\end{tabular}

\subsection{Procedures}

After selecting subjects based on the OPT results, the reading comprehension test (the Reading Section of Paper-Based TOEFL (1996)) was administered as the pretest. Afterwards, six sessions of treatments were offered in both experimental groups: Narrative experimental group was treated with three narrative texts and Non-narrative experimental group with three non-narrative texts. Two treatment sessions were devoted to each text. Finally, after treatments, the participants were given the post-test.

The treatment sessions in both groups were based on using communicative reading strategies in reading narrative and non-narrative texts. Krashen and Terrell (1983) outline communicative reading strategies as: (I) Reading for meaning, (II) not looking up every word, (III) predicting meaning, and (IV) using the context.

Conceiving reading as a communicative process leads to an important conclusion. Students do not need any more to know the meaning of every individual word to understand the text to recreate the author's intended meaning (Chastain, 1988). To Grellet (1981), successful readers do not focus their attention on the meaning of individual words and sentences; rather, they first try to achieve a total understanding and then move toward detailed aspects of reading comprehension.

\subsection{Data Analysis and Results}

\subsubsection{Within Group Comparisons: paired-samples t-test}

Part of the statistical analyses relevant to the present study was done through paired-samples t-tests; the results are reported below. A paired-samples t-test was carried out to examine the effect of the treatments on the participants' scores on the reading comprehension test in Narrative experimental group. As tables 3 and 4 show, the subjects' scores significantly increased in reading comprehension from the pretest $(\mathrm{M}=19.46, S D=4.21)$ to the post-test $(\mathrm{M}=23.10$, $S D=3.51), \mathrm{t}(27)=-5.74, p<.0005$ (two tailed). The mean increase in reading comprehension scores was 3.64 with a $95 \%$ confidence interval ranging from -4.94 to -2.34 ; the Eta squared statistics (.54) indicates a great effect size. Therefore, the null hypothesis (1) is rejected at the .05 level. Thus, the results indicate a significant relationship between using narratives in L2 classes and improvement of learners' reading comprehension ability.

Table 3. Paired Samples Statistics(Narrative Experimental group)

\begin{tabular}{llllcc}
\hline & & Mean & N & Std. Deviation & Std. Error Mean \\
\hline \multirow{2}{*}{ Pair 1 } & Pretest & 19.46 & 28 & 4.21 & .795 \\
\cline { 2 - 6 } & Posttest & 23.10 & 28 & 3.51 & .663 \\
\hline
\end{tabular}

Table 4. Paired Samples T-test (Narrative Experimental group)

\begin{tabular}{|c|c|c|c|c|c|c|c|c|}
\hline & \multicolumn{5}{|c|}{ Paired Differences } & \multirow[t]{3}{*}{$\mathrm{t}$} & \multirow[t]{3}{*}{$\mathrm{df}$} & \multirow{3}{*}{$\begin{array}{l}\text { Sig. (2- } \\
\text { tailed) }\end{array}$} \\
\hline & \multirow[t]{2}{*}{ Mean } & \multirow[t]{2}{*}{$\begin{array}{c}\text { Std. } \\
\text { Deviation }\end{array}$} & \multirow{2}{*}{$\begin{array}{l}\text { Std. } \\
\text { Error } \\
\text { Mean }\end{array}$} & \multicolumn{2}{|c|}{$\begin{array}{l}\text { 95\% Confidence Interval } \\
\text { of the Difference }\end{array}$} & & & \\
\hline & & & & Lower & Upper & & & \\
\hline Pre -, Posttest & -3.64 & 3.35 & .634 & -4.94 & -2.34 & -5.74 & 27 & .000 \\
\hline
\end{tabular}


A paired-samples t-test was also performed to evaluate the effect of the treatments on the subjects' scores on the reading comprehension test in Non-narrative experimental group. Tables 5 and 6 indicate a significant increase in reading comprehension scores from the pretest $(\mathrm{M}=16.80, S D=4.08)$ to the post-test $(\mathrm{M}=19.31, S D=3.26), \mathrm{t}(34)=-3.89, p<$ .05 (two tailed). The mean increase in reading comprehension scores (from pretest to post-test) was 2.51 with a $95 \%$ confidence interval ranging from -3.82 to -1.20 . The Eta squared statistics (.30) indicated a large effect size. Therefore, the null hypothesis (2) is rejected at the .05 level. So, we can come to the conclusion that there is a significant relationship between using non-narratives in EFL classes and improvement of L2 learners' reading comprehension ability.

Table 5. Paired Samples Statistics(Non-narrative Experimental group)

\begin{tabular}{llllcc}
\hline & & Mean & N & Std. Deviation & Std. Error Mean \\
\hline \multirow{2}{*}{ Pair 1 } & Pretest & 16.80 & 35 & 4.08 & .690 \\
\cline { 2 - 6 } & Posttest & 19.31 & 35 & 3.26 & .551 \\
\hline
\end{tabular}

Table 6. Paired Samples T-test (Non-narrative Experimental group)

\begin{tabular}{|c|c|c|c|c|c|c|c|c|}
\hline \multirow{3}{*}{$\begin{array}{c}\text { Pair } \\
1\end{array}$} & \multicolumn{5}{|c|}{ Paired Differences } & \multirow[t]{3}{*}{$\mathrm{t}$} & \multirow[t]{3}{*}{$\mathrm{df}$} & \multirow{3}{*}{$\begin{array}{l}\text { Sig. (2- } \\
\text { tailed) }\end{array}$} \\
\hline & \multirow[t]{2}{*}{ Mean } & \multirow[t]{2}{*}{$\begin{array}{c}\text { Std. } \\
\text { Devia } \\
\text { tion }\end{array}$} & \multirow[t]{2}{*}{$\begin{array}{l}\text { Std. } \\
\text { Error } \\
\text { Mean }\end{array}$} & \multicolumn{2}{|c|}{$\begin{array}{l}95 \% \text { Confidence } \\
\text { Interval of the } \\
\text { Difference }\end{array}$} & & & \\
\hline & & & & Lower & Upper & & & \\
\hline Pre-, Posttest & -2.51 & 3.82 & .646 & -3.82 & -1.20 & -3.89 & 34 & .000 \\
\hline
\end{tabular}

Another paired-samples t-test was used with the control group to measure the effect of regular educational programs on subjects" scores on the reading comprehension test. Based on the results tabulated in tables 7 and 8, no significant difference was observed in scores from the pretest $(\mathrm{M}=23.04, S D=2.34)$ to the post-test $(\mathrm{M}=21.29, S D=4.27), \mathrm{t}(23)$ $=1.91, p>.05$ (two-tailed). The mean decrease was -1.75 with a $95 \%$ confidence interval ranging from -.13 to 3.63 . Consequently, one can come to the conclusion that there is not any statistically significant effect for regular educational programs from the pretest to the post -test.

Table 7. Paired Samples Statistics (Control group)

\begin{tabular}{cccccc}
\hline & Mean & $\mathrm{N}$ & Std. Deviation & Std. Error Mean \\
\hline \multirow{2}{*}{ Pair 1 } & Pretest & 23.04 & 24 & 2.34 & .47 \\
\cline { 2 - 6 } & Posttest & 21.29 & 24 & 4.27 & .87 \\
\hline
\end{tabular}

Table 8. Paired Samples T-test (Control group)

\begin{tabular}{|c|c|c|c|c|c|c|c|c|}
\hline & \multicolumn{5}{|c|}{ Paired Differences } & \multirow[t]{3}{*}{$\mathrm{t}$} & \multirow[t]{3}{*}{$\mathrm{df}$} & \multirow{3}{*}{$\begin{array}{l}\text { Sig. (2- } \\
\text { tailed) }\end{array}$} \\
\hline & \multirow[t]{2}{*}{ Mean } & \multirow[t]{2}{*}{$\begin{array}{c}\text { Std. } \\
\text { Deviation }\end{array}$} & \multirow[t]{2}{*}{$\begin{array}{l}\text { Std. } \\
\text { Error } \\
\text { Mean }\end{array}$} & \multicolumn{2}{|c|}{$\begin{array}{l}95 \% \text { Confidence } \\
\text { Interval of the } \\
\text { Difference }\end{array}$} & & & \\
\hline & & & & Lower & Upper & & & \\
\hline Pre-, Posttest & 1.75 & 4.47 & .91 & -.13 & 3.63 & 1.91 & 23 & .068 \\
\hline
\end{tabular}

3.4.2 Between Group Comparisons: Independent-samples t-test

This section is devoted to statistical analyses based on independent-samples t-tests to make between-groups comparison in the pretest and post-test occasions.

As mentioned before, those who participated in this study were homogenous in their general English proficiency according to OPT results. However, as seen in tables 3 and 5, for the pretest occasions the mean scores of Narrative and Non-narrative experimental groups were 19.46 and 16.80, respectively. Therefore, although the experimental groups were homogeneous in terms of general proficiency, in their reading abilities they showed differences in scores according to independent sample t-test results. Thus, to solve the problem, based on reading comprehension test results (pretest), the participants whose score placed in one standard deviation (4.31) on either side of the mean (17.98) were chosen to support the assumption of homogeneity. Consequently, 16 subjects in Narrative experimental group and 26 ones in Non-narrative experimental group remained for the comparison between the two experimental groups.

Using an independent-samples t-test, the pretest scores of the two experimental groups were compared (Tables 9 and 10). The result indicated no significant difference in scores between Narrative experimental group $(\mathrm{M}=18.25, \mathrm{SD}=$ 1.80 ) and Non-narrative experimental group, $\mathrm{M}=17.84, \mathrm{SD}=2.60 ; \mathrm{t}(38.68)=.59, \mathrm{p}=.55$ (two-tailed). The mean 
difference (mean difference $=.41,95 \%$ CI: -1.8 to .98 ) was not significant, and the Eta squared was calculated (.007), which is very small and shows no significant size effect.

Table 9. Group Statistics ( Narrative and Non-narrative Experimental groups/Pretest)

\begin{tabular}{llcccc}
\hline & & N & Mean & $\begin{array}{c}\text { Std. } \\
\text { Deviation }\end{array}$ & $\begin{array}{c}\text { Std. Error } \\
\text { Mean }\end{array}$ \\
\hline Pretest & Narrative Experimental Group & 16 & 18.25 & 1.80 & .45 \\
& Non-Narrative Experimental & 25 & 17.84 & 2.60 & .52 \\
& Group & & & & \\
\hline
\end{tabular}

Table 10. Independent Samples T-test ( Narrative and Non-narrative Experimental groups/Pretest)

\begin{tabular}{|c|c|c|c|c|c|c|c|c|c|}
\hline \multirow{3}{*}{ Pretest } & \multicolumn{2}{|c|}{$\begin{array}{c}\text { Levene's } \\
\text { Test for } \\
\text { Equality of } \\
\text { Variances }\end{array}$} & \multicolumn{7}{|c|}{ t-test for Equality of Means } \\
\hline & \multirow[t]{2}{*}{$\mathrm{F}$} & \multirow[t]{2}{*}{ Sig. } & \multirow[t]{2}{*}{$\mathrm{t}$} & \multirow[t]{2}{*}{$\mathrm{df}$} & \multirow[t]{2}{*}{$\begin{array}{l}\text { Sig. (2- } \\
\text { tailed) }\end{array}$} & \multirow[t]{2}{*}{$\begin{array}{c}\text { Mean } \\
\text { Difference }\end{array}$} & \multirow[t]{2}{*}{$\begin{array}{l}\text { Std. Error } \\
\text { Difference }\end{array}$} & \multicolumn{2}{|c|}{$\begin{array}{c}95 \% \\
\text { Confidence } \\
\text { Interval of the } \\
\text { Difference } \\
\end{array}$} \\
\hline & & & & & & & & Lower & Upper \\
\hline $\begin{array}{l}\text { Equal } \\
\text { variances } \\
\text { assumed }\end{array}$ & 5.21 & .02 & -.54 & 39 & .58 & -.41 & .747 & -1.92 & 1.10 \\
\hline $\begin{array}{l}\text { Equal } \\
\text { variances not } \\
\text { assumed }\end{array}$ & & & -.59 & 38.68 & .55 & -.41 & .69 & -1.80 & .98 \\
\hline
\end{tabular}

For a second time, the post-test scores of Narrative and Non-narrative experimental groups were compared via an independent-samples t-test. The results (Tables 11 and 12) revealed a statistically significant difference in the scores of Narrative experimental group $(M=22, S D=2.9)$ and Non-narrative experimental group, $\mathrm{M}=19.76, S D=3.19 ; t(39)=$ $-2.24, p=.03$ (two-tailed). The difference in the means (mean difference $=2.24,95 \%$ CI: -4.25 to -.22 ) was significant, too. Eta squared was calculated (.24) which is an implication of a large size effect.

Table 11. Group Statistics (Narrative and Non-narrative Experimental groups/Post-test)

\begin{tabular}{llcccc}
\hline & & N & Mean & $\begin{array}{c}\text { Std. } \\
\text { Deviation }\end{array}$ & Std. Error Mean \\
\hline Post-test & Narrative Experimental Group & 16 & 22 & 2.9 & .74 \\
& Non-Narrative Experimental Group & 25 & 19.76 & 3.19 & .63 \\
\hline
\end{tabular}

Table 12. Independent Samples T-test ( Narrative and Non-narrative Experimental groups/Posttest)

\begin{tabular}{|c|c|c|c|c|c|c|c|c|c|}
\hline \multirow{3}{*}{ Pretest } & \multicolumn{2}{|c|}{$\begin{array}{l}\text { Levene's } \\
\text { Test for } \\
\text { Equality of } \\
\text { Variances }\end{array}$} & \multicolumn{7}{|c|}{ t-test for Equality of Means } \\
\hline & \multirow[t]{2}{*}{$\mathrm{F}$} & \multirow[t]{2}{*}{ Sig. } & \multirow[t]{2}{*}{$\mathrm{t}$} & \multirow[t]{2}{*}{ df } & \multirow[t]{2}{*}{$\begin{array}{l}\text { Sig. } \\
(2- \\
\text { tailed })\end{array}$} & \multirow[t]{2}{*}{$\begin{array}{c}\text { Mean } \\
\text { Difference }\end{array}$} & \multirow[t]{2}{*}{$\begin{array}{l}\text { Std. Error } \\
\text { Difference }\end{array}$} & \multicolumn{2}{|c|}{$\begin{array}{c}95 \% \text { Confidence } \\
\text { Interval of the } \\
\text { Difference }\end{array}$} \\
\hline & & & & & & & & Lower & Upper \\
\hline $\begin{array}{c}\text { Equal } \\
\text { variances } \\
\text { assumed } \\
\end{array}$ & .001 & .97 & -2.24 & 39 & .03 & -2.24 & .99 & -4.25 & -.22 \\
\hline $\begin{array}{c}\text { Equal } \\
\text { variances not } \\
\text { assumed }\end{array}$ & & & -2.27 & 33.67 & .029 & -2.24 & .98 & -4.23 & -.24 \\
\hline
\end{tabular}

The above mentioned results indicated that the mean difference in the post-test, in comparison with the pretest, has significantly increased. In other words, the difference between the two groups has increased in reading comprehension ability (from .41 to 2.24). Another important point is the magnitude of Eta squared which in the pretest was .007 (very small) and .11 (large) in the post-test. So, the null hypothesis (3) is rejected at the .05 level. Accordingly, we may say that there is a significant priority in using narratives over non-narratives in EFL classes and improvement of Iranian 
EFL learners' reading comprehension ability. That is, narratives are more effective than non-narrative texts in L2 learners' development of reading comprehension ability.

\section{Discussion}

This study investigated possible effects of using narrative texts in EFL classrooms on L2 learners' reading comprehension ability compared to non-narrative texts. It also examined the effects of using non-narrative texts in the same situation on students' reading comprehension ability. The results of data analyses suggest some findings which are briefly explained as follows.

First of all, the results showed that using narrative texts, short stories, in Narrative experimental group, have positive effects on enhancing students' reading comprehension ability. On the other hand, in Non-narrative experimental group, reading comprehension improvement under the influence of using non-narrative texts turned out to be significant, too. Nevertheless, there appears to be a discrepancy between the two groups that should be taken into consideration carefully. Based on the statistical results, the magnitude of the difference between the means of Narrative and Nonnarrative experimental groups in the pretest was not significant; however, the difference in the post-test occasion became completely significant. In other words, the difference between the two groups' reading comprehension ability has increased after treatments. This shows that narrative texts/short stories are more effective to develop learners' reading comprehension ability than non-narrative texts.

There is no doubt that one of the noteworthy dimensions of human's nature is the sense of curiosity and his deep desire to explore the world around. As Park, Mahoney, and Greenwell (2010: 435) argue, “... curiosity has been regarded as one of the critical motivators of human exploratory behaviors and has been investigated in many domains such as the educational, occupational, and recreational sectors". Reading narratives seems to be able to satisfy human curiosity in a number of aspects. Through hidden and implied aspects of stories, readers' curiosity arises which makes them to keep on reading until the story is finished and they come to a particular understanding or discovery. Exploration through narratives, as an authentic window to other cultures, in educational context in general and language teaching environments in particular allows the students become acquainted with new aspects of life within the framework of L2 culture. It also allows them to investigate cultural differences that exist between L1 and L2 societies and thereby to reach a better understanding of the two cultures when compared to each other. During the treatment sessions, most of the students stated that they had enjoyed reading the stories since the hidden and implied aspects of stories made them more sensitive to explore the lines on the stories and delve into the deeper layers of the text to get new meanings and explore the other side of the mountain.

Mckay (1982, p. 531) maintains that "to the extent that students find reading literature delightful and enjoyable, it may enhance their motivation to make an effective interaction with a text and, consequently, develop their reading proficiency". Van $(2009$, p.8) also explains that "the use of literature facilitates language learning because, when it is properly introduced, students enjoy literary style". The researchers' observations of students' attitudes in Narrative experimental group suggest that the majority of students found reading short stories more delightful and enjoyable than the other texts of reading. Krashen (2003) proposes the pleasure hypothesis. The hypothesis states that "pedagogical activities that promote language acquisition are enjoyable, and those that do not are not enjoyable" (p. 22). Needless to say, some activities may be very enjoyable but may not be promoting at all. Enjoyment is no guarantee of effectiveness but is highly influential to promote motivation amongst the students and consequently may lead to promotion of language acquisition. Based on our observations, students' feedback (reading short stories is an enjoyable task to do), results and findings, using short stories in EFL classes is, at least in part, in line with Krashen's pleasure hypothesis.

Bakhtin (1975 cited in Atkinson \& Mitchell, 2010) stipulates that Novel narratives bring into play more ambiguity to the language that leads to the generation of more space for diversity of interpretations, explanations or arguments of a single narrative. In general, these types of texts involve more attempts on the part of readers to follow and decode what the author is going to communicate. Put it differently, the use of appropriate short narratives in EFL/ESL environments provides language learners with valuable opportunities for class discussions which encourage them to make use of a number of thinking skills such as analytical, problem-solving, critical, creative, and reflective thinking skills. In this way, one may conclude that through using narratives in EFL/ESL classrooms, the way may be paved toward the development of critical thinking ability. No need to say that development of language learners' cognitive analytical abilities can increase their language skills, particularly reading comprehension ability. In this study, it is likely that the development of readers' cognitive analytical abilities, because of using narratives, has led to further increase in Narrative group's reading comprehension scores in the post-test occasion compared to Non-narrative group's.

Overall reading comprehension is highly under the influence of the level of previous or background knowledge that the readers have about a topic (Klauda \& Guthrie, 2008). The level of background knowledge positively influences the ability of readers to infer meaning in texts of social studies (Tarchi, 2009), particularly literary texts. Ausubel believes that "learning takes place in the human organism through a meaningful process of relating new events or items to already existing cognitive concepts or propositions -hanging new items on existing cognitive pegs" (cited in Brown, 2006 p.91). Themes of literary texts, regardless of their types (poetry or prose) or the language they are written in (Persian, English, Russian, etc.) by and large center on concepts like the praise of love, truth, devotion, justice, etc. on the one hand, and condemnation of ambition, betrayal, lies, greed, lust and gluttony on the other. These commonalities that exist in the literature of nations may act as background knowledge or already existing cognitive concepts that language learners bring to L2 classes from their previous experiences of reading literature (narratives) even in their native language. Thus, using literary texts enables language teachers to bring into play students' previous knowledge of (L1) literature and in this way facilitates the process of better learning and comprehension improvements. Our observations showed that students in Narrative experimental group had more to offer in class discussions or 
presentations. The treatments they received, at least to a certain extent, might have evoked their previous familiarity with narrative texts (short stories) and thus have enabled them to do better interactions with narrative texts which led to better comprehension and restatements.

\section{Conclusion \& Implication}

Along with variety of important factors influencing on language teaching/learning, pedagogical factors are of strategic and crucial significance. Of these notable factors are textbooks and the contents of the teaching materials, which play principal roles to construct a high quality of education. Producers of learning materials and textbook designers should enrich the learning materials as much as possible. In doing so, they are supposed to be in close connection with educational researchers for being aware of the findings of new research in educational environments. The findings of the present research may make a positive contribution to the development of materials for EFL/ESL environments in general, and for L2 learners with various language proficiency in particular. Regarding the outcomes of this study, concerning the relative superiority of using narrative texts in language learning environments, short stories offer certain advantages for writing textbooks and designing instructional materials in language teaching territory; namely, this genre includes short textual materials which make the task for both groups, students and teachers, easier to handle.

Since the use of narratives, short stories, in EFL classes brings into play more hidden and implied aspects that lead to the generation of more space for diversity of interpretations, explanations or argumentations, it may involve more attempts on the part of readers to follow and decode what the author intends to communicate. In this respect, EFL teachers can provide students with more short stories either for classroom reading activities or out-of-class activities to pave the way for more developments of readers' cognitive analytical abilities.

Among recent manifestations of approaches and methods, Communicative Language Teaching (CLT) has come into view as the centre of attention in language educational contexts around the world. CLT lays great emphasis on classroom interactions, learner-oriented education, authenticity, and taking into consideration the learners themselves and their background experiences as meaningful contributions to the learning process. Van (2009) thinks that using literary texts (Literature) in L2 teaching is in line with the CLT principles. It seems that short narratives, as one of the most popular types of literary texts, display some characteristics which maintain perfect harmony with CLT. For instance, short stories invite L2 learners to engage in a more active and extended discussion of their involvement with the text and their personal experiences relevant to the world of the text, through which classroom interactions, learners' own experiences as important contributors to learning, and learner-orientedness are covered. On the other hand, literary texts in general and short narratives in particular, serve many causes in language teaching environments; they are used mostly as an authentic window to the world of a foreign culture and society. So, narrative texts (short stories) are able to deal with the issue of authenticity as one of the main points emphasized by CLT and seem to be completely in line with the CLT principles.

According to Mckay (1982, p. 531), "to the extent that students find reading literature delightful and enjoyable, it may enhance their motivation to make an effective interaction with a text and, consequently, develop their reading proficiency". Based on the findings and observation of this study, reading short stories provides EFL students with more empowerment which may lead to more pleasure and enjoyment. Therefore, language teachers in EFL classrooms can use narrative texts to provide a more vibrant environment to promote motivation amongst their students.

This study shows that narratives, as one of the most popular types of literary texts, display some characteristics which maintain perfect harmony with learner-oriented approaches. It moreover shows that using short stories by teachers may highly encourage cooperative activities between students and, in this way, may provide students with opportunities to develop authentic relationships with their peers.

\section{References}

Aghagolzadeh, F., \& Tajabadi, F. (2012). A Debate on Literature as a Teaching Material in FLT. Journal of Language Teaching and Research, 3 (1), 205-210.

Ahmadian, M. (2011). Using Narrative Literature to Develop Second Language Learners Intercultural Communication Competence. Paper presented at: The 4th International Conference on Across Languages and Intercultural Communication. Universita Ca' Foscari, Venezia, Italy.

Atkinson, B., \& Mitchell, R. "Why Didn"t They Get It?" "Did They Have to Get It?" What Reader Response Theory Has to Offer Narrative Research and Pedagogy? International Journal of Education \& the Arts , 11 (7), 1-24.

Bakhtin, M. (1975). The dialogic imagination: Four essays. Austin: University of Texas Press.

Barthes, R. (1977). Image, Music, Text. New York: Hill \& Wang.

Birlik, N., \& Salli-Copur, D. (2007). Short stories in teaching foreign language skills. Academic Exchange Quarterly , $11(1), 93-98$.

Brown, H. D. (2006). Principles of Language Learning and Teaching (5 $5^{\text {th }}$ ed.). Pearson ESL.

Carter, R. (2007). Literature and language teaching 1986-2006: a review. International Journal of Applied Linguistics , 17 (1), 3-13.

Chastain, K. (1988). Developing Second Language Skills: Theory and Practice (3 ${ }^{\text {rd }}$ ed.). Orlando: Harcourt Brace Jovanovich.

Davis, R. H. (n.d.). The Hungry Man was Fed. [Online] Available: http://www.readbookonline.net/readOnLine/10618/ (March 10, 2012)

Deutschman, P. (2012). It Happened on a Brooklyn Subway. In J. Van (Ed.), Do You Believe in Miracles? Amazing True Stories of God at Work. Harvest House Publisher. 
Edmondson, W. (1997). The role of literature in foreign language learning and. In A. Mauranen, \& K. Sajavaara (Eds.), Applied linguistics across disciplines. AILA Review No. 12, 42-55.

Grellet, F. (1981). Developing reading skills. Cambridge: Cambridge University Press.

Hester, E. J. (2010). Narrative Correlates of Reading Comprehension in African American Children. Contemporary Issues in Communication Science and Disorders , 37, 73-85.

Hişmanoğlu, M. (2005). Teaching English through Literature. Journal of Language and Linguistic Studies , 1 (1), $53-$ 66.

Holloway, S. (2009). Using literature in learning contexts to address contentious issues of difference, culture, power, and privilege in the classroom. Transformative Dialogues: Teaching and Learning Journal , March, 1-24.

Johnson, K. E., \& Golombek, P. R. (2011). The Transformative Power of Narrative in Second Language Teacher Education. TESOL Quarterly, 45 (3), 486-509.

Kafka, F. (1940). Letter to Oskar Pollak. [Online] Available: http://en.wikiquote.org/wiki/Franz_Kafka (July 10, 2012). Khatib, M., Rezaei, S., \& Derakhshan, A. (2011). Literature in EFL/ESL Classroom. English Language Teaching , 4 (1), 201-208.

Klauda, S. L., \& Guthrie, J. T. (2008). Relationships of three components of reading fluency to reading comprehension. Journal of Educational Psychology, 100 (2), 310-321.

Knight, S. D. (2011). Using narrative to examine positionality: Powerful pedagogy in English education. English Teaching: Practice and Critique, 10 (2), 49-64.

Kong, J., Powers, S., Starr, L., \& Williams, N. (2012). Connecting English Language Learning and Academic Performance: A Prediction Study. American Educational Research Association.

Kramsch, C. (1993). Context and Culture in Language Teaching. Oxford: Oxford University Press.

Krashen, S. D. (2003). Explorations in Language Acquisition and Use: The Taipei Lectures. Portsmouth, NH: Heinemann.

Krashen, S. D. (1985). The Input Hypothesis: Issues and Implications. New York: Longman.

Krashen, S. D., \& Terrell, T. D. (1983). The natural approach: Language acquisition in the classroom. Pergamon Press. Mar, R., Otaley, K., Harish, J., de la Paz, J., \& Peterson, J. (2006). 'Bookworms versus nerds: Exposure to fiction versus non-fiction, divergent associations with social ability, and the simulation of fictional social worlds'. Journal of Research in Personality, 40 (5), 694-712.

McKay, S. (2001). Literature as Content for ESL/EFL. In M. Celce-Murcia (Ed.), Teaching English as a Second or Foreign Language. Heinle \& Heinle.

McKay, S. (1982). Literature in the ESL Classroom. TESOL QUARTERLY, 16 (4), 529-536.

Mystery Surrounding the Phoenix Lights: Evidence of UFO Sighting? (n.d.). [Online] Available: http://www.123helpme.com/view.asp?id=10659 (May 12, 2012).

Musen, L. (2010). Early Reading Proficiency. Annenberg Institute for School Reform.

Nash, C. (1994) Narrative in culture. London: Routledge.

Oster, J. (1989). Seeing with different eyes: Another view of literature in the ESL class. TESOL Quarterly, 23 (1), 85103.

Paran, A. (2008). The role of literature in instructed foreign language learning and teaching: evidence-based survey. Language Teaching , 41 (4), 465-496.

Park, S. H., Mahoney, D. F., \& Greenwell, T. C. (2010). The Measurement of Sport Fan Exploratory Curiosity. Journal of Sport Management, 24, 434-455.

Pretorius, E. J. (2002). "Reading ability and academic performance in South Africa: are we fiddling while Rome is burning?". Language Matters , 33, 169-196.

Rahimi, M., Mirzaei, A., \& Heidari, N. (2012). How do Successful EFL Readers Bridge between Multiple Intelligence and Reading Strategies? World Applied Sciences Journal, 17 (9), 1134-1142.

Ronnqvist, L., \& Sell, R. D. (1994). Teenage books for teenagers: reflections on literature in language education. ELT Journal , 48, 125-132.

Rutten, K., Mottart, A., \& Soetaert, R. (2010). Narrative and Rhetoric in Social Work Education. BritishJournal of Social Work, 40, 480-495.

Sage, H. (1987). Incorporating Literature in ESL Instruction. New Jersey: Prentice-Hall, Inc.

Savvidou, C. (2004). An integrated approach to the teaching of literature in the EFL classroom. The Internet TESL Journal , 12. [Online] Available: http://iteslj.org/Techniques/Savvidou-Literature.html (July 10, 2012).

Schank, R. C., \& Abelson, R. P. (1995). "Knowledge and memory: The real story". In S. Robert, \& J. R. Wyer (Eds.), Knowledge and Memory: The real story. Hillsdale, NJ: Lawrence Erlbaum.

Smith, B. (2007). The state of the art in narrative inquiry: Some reflections. Narrative Inquiry, 17 (2), 391-398.

Smith-Yackel, B. (1998). My Mother Never Worked. In M. L. Conlin (Ed.), Patterns; A Short Prose Reader (5 ed.). New York: Houghton Mifflin Company.

Tarchi, C. (2009). Reading comprehension of informative texts in secondary school: A focus on direct and indirect effects of reader"s prior knowledge. Learning and Individual Differences , 20, 415-420.

Turner, L. M. (2012, March). Encouraging Professional Growth among Social Work Students through Literature Assignments: Narrative Literature"s Capacity to Inspire Professional Growth and Empathy. British Journal of Social Work, 1-19. doi:10.1093/bjsw/bcs011.

Van, T. (2009). The relevance of literary analysis to teaching literature in the EFL classroom. English Teaching Forum, $3,2-9$. 